\section{Blossom Thinning in Apple and Peach with an Essential Oil}

\author{
Stephen S. Miller ${ }^{1}$ and Thomas Tworkoski \\ U.S. Department of Agriculture, Agricultural Research Service, Appalachian \\ Fruit Research Station, 2217 Wiltshire Road, Kearneysville, WV 25430
}

Additional index words. crop load, phytotoxicity, defoliation, Malus $\times$ domestica, Prunus persica, eugenol, clove oil

\begin{abstract}
A series of experiments was conducted with apple (Malus $\times$ domestica) and peach [Prunus persica (L.) Batsch] from 2003 to 2008 to evaluate the flower thinning efficacy of eugenol and a eugenol-based essential oil. Flower thinning effects by hand defoliation and alternative chemical agents were compared with eugenol in different years. Eugenol or the eugenol-based contact herbicide Matran 2 EC (or Matratec AG) produced noticeable phytotoxicity to floral parts and exposed leaf tissue within $15 \mathrm{~min}$ to $1 \mathrm{~h}$ after application and injury was proportional to rate. At the highest rates $(8 \%$ and $10 \%)$, eugenol resulted in complete burning of all exposed tissue except bark tissue, in which there were no visible signs of injury. Within 3 to 4 weeks of application, phytotoxicity was difficult to observe even at the higher rates of eugenol. In companion experiments, hand defoliation of young leaves at bloom resulted in abscission of young fruitlets in apple, but not in peach, indicating that eugenol may cause thinning by multiple mechanisms. Ammonium thiosulfate (ATS) $\left[49 \mathrm{~L} \cdot \mathrm{ha}^{-1}\right.$ or $\left.6.0 \%(\mathrm{v} / \mathrm{v})\right]$ provided thinning in peach and showed little or no phytotoxicity, but the response was inconsistent. ATS was also inconsistent in thinning apple. The thinning response from monocarbamidedihydrogen sulphate (MCDS; Wilthin) at 3.2\% (v/v) was inconsistent in peach. At the rate used, MCDS caused some phytotoxicity on peach. Applications of $1 \%$ to $2 \%$ eugenol appear promising, but good blossom coverage is critical for thinning. Furthermore, eugenol formulations need improvement to ensure uniform coverage for more predictable thinning.
\end{abstract}

Apple and peach trees normally produce significantly more fruit than the tree can carry to a marketable size crop (Dennis, 2000; Wertheim, 2000). Hand thinning at 35 to $60 \mathrm{~d}$ after full bloom is the standard practice to reduce crop load and increase fruit size at harvest. Hand thinning is expensive and, with recent labor shortages, is more problematic for growers to complete in a timely manner. Chemical thinners have long been available and used in apple production (Byers, 2003). Thinning at bloom time results in larger fruit at harvest than achieved with the later hand thinning (Byers and Lyons, 1985). Removing $50 \%$ of peach flowers increased average size of the remaining fruit and increased overall crop value (Myers et al., 2002). Chemical thinning of peach flowers reduced the estimated cost of hand thinning up to \$310 U.S. per ha (Southwick et al., 1995). A number of materials (Byers, 1999; Fallahi, 1997; Moran et al., 2000; Southwick et al., 1995; Wilkens

Received for publication 15 Mar. 2010. Accepted for publication 28 May 2010.

We gratefully acknowledge the technical assistance of V. Larry Crim, Christian Hott, Anthony Rugh, and Kevin Webb in these studies.

Mention of a trademark, proprietary product, or vendor does not constitute a guarantee or warranty of the product by the USDA and does not imply its approval to the exclusion of other products or vendors that also may be suitable.

${ }^{1}$ To whom reprint requests should be addressed; e-mail stephen.miller@ars.usda.gov. hance the thinning activity of mild chemical thinners (Byers and Carbaugh, 1991). McArtney et al. (2006) reported that liquid lime sulfur (LS) and fish oil applied at bloom time suppressed Pn and likely contributed to the thinning response of these materials.

Currently, buds, blossoms, and fruit can be removed by hand or with chemicals, but the number of chemical thinners available is limited, especially in peach, and those available are not always effective (Costa et al., 2004). There is a need for new chemical thinners, especially "environmentally friendly thinners," to replace the costly, labor-intensive hand thinning that is currently used by growers (Dennis, 2000).

Several chemicals, including sodium chloride, LS, acetic acid, and soybean oil, have been found to have potential flower-thinning application for organic apple orchards (Moran et al., 2000; Stopar, 2008). Tworkoski (2002) reported that an essential oil was effective as a contact herbicide and that such plant-derived oils may be acceptable for organic management systems. He found that low rates could cause burn-back of sensitive plant tissue without killing the plant. The a.i. in several essential oils is eugenol [2-methoxy-4-(2-propenyl)phenol] (Fig. 1). This report examines the efficacy of eugenol and a eugenol-based contact herbicide, Matran 2EC (50\% clove oil; EcoSMART Technologies, Inc., Franklin, $\mathrm{TN})$ or Matratec AG (50\% clove oil; ClawEl Specialty Products, Pleasant Plains, IL), as blossom thinners in apple and peach. Rates, application techniques, timing, and frequency of application were modified each year to address pressing questions raised by previous trials with this novel, newly patented thinning agent, eugenol. In selected years, thinning effects of eugenol were compared with hand defoliation and with known chemical thinners. The fertilizer, ATS, which has demonstrated bloom thinning response and is being used by some commercial growers, was included in selected tests. Several tests also included LS, 6-benzyladenine (6-BA), carbaryl, or the commercially available bloom thinner, Wilthin (Entek Corp., Brea, CA). The objective was to determine the effectiveness of different concentrations and time of application of an essential oil, represented by eugenol, on blossom thinning, yield, and fruit size distribution.

\section{Materials and Methods}

Tests were conducted from 2003 to 2008 on bearing apple and peach trees planted at the Appalachian Fruit Research Station, Kearneysville, WV. Except where noted, all data in this study were analyzed with analysis of variance using SAS Proc GLM or SAS Proc MIXED (SAS Institute Inc., Cary, NC) and treatment means separated with the Duncan's multiple range test $(P \leq 0.05)$.

Initial bloom thinning sprays in 2003 were applied with a hand wand sprayer and sprays to peach in 2005 were applied with a handgun high-pressure sprayer. Based on observed phytotoxicity to flowers and/or 


\section{Eugenol}

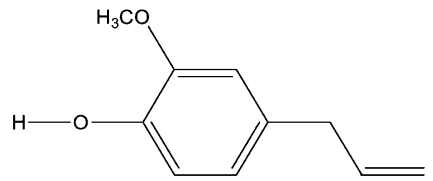

Fig. 1. Chemical structure of eugenol, the active ingredient of several essential oils.

young leaf tissue, it was obvious that handgun applications lacked uniform coverage within and between individual tree canopies despite every effort to apply a uniform spray. Therefore, all sprays beginning in 2006 and after as well as sprays to apple in 2005 were applied with a Durand-Wayland Model AF100-32 3-pt. hitch airblast sprayer (DurandWayland, LaGrange, GA) operating between 896 and $1034 \mathrm{kPa}$. The airblast sprayer's axial fan was operated at the "high-speed" setting for large apple and peach trees (over $4.5 \mathrm{~m}$ tall) and at "low speed" for medium-stature trees (3 to $4 \mathrm{~m}$ tall). The fan was placed in "neutral" when spraying apple trees on Budagovsky.9 (B.9) dwarfing rootstock and the low stature (2.5 m tall or less) 'John Boy'/'Halford' peach trees. Operating the fan in neutral prevented spray drift to adjacent treatment rows in these plantings. In all studies, sprays were applied in a water carrier on a percent $\mathrm{v} / \mathrm{v}$ basis unless indicated otherwise.

\section{Apple}

2003 tests. Initial work in 2003 was to determine general foliar and blossom injury response to increasing rates $(0 \%$ to $10 \%)$ of eugenol on apple and peach. Naturally derived eugenol, extracted from cinnamon, Cinnamomum zeylanicum, and clove, Syzgium aromaticum, 99\% a.i., was obtained from Citrus and Allied Essences, Ltd. (Floral Park, NY). Eugenol was prepared as a suspension in water and applied with agitation using a handheld wand sprayer (Sure Shot; Milwaukee Sprayer Mfg. Co., Inc., Milwaukee, WI) to flowers to the point of first drip.

Eugenol was applied to 7-year-old apple trees ['Ace Spur Red Delicious' on Malling.7 (M.7) rootstock] on 23 Apr. 2003 when "king" blossoms were fully opened and subtending flowers were just opening. Temperatures were $18{ }^{\circ} \mathrm{C}$ under partly sunny conditions. One hundred five cluster groups of flowers were evaluated for damage $24 \mathrm{~h}$ after application. Surviving fruit from the original clusters were counted 1 and 2 months after application. Apples were harvested on 17 Sept. 2003 from each treated tree. Total fruit number, weight, and size of individual fruit were measured.

2005 tests. Three spray treatments were applied with the airblast sprayer to 'Royal Gala'/M.26 apple trees beginning with their eighth leaf in the orchard with at least $50 \%$ of the available spurs flowering: ATS (Amthio; Allied Chemical Company, Houston, TX), Matran EC (50\% clove oil containing 81\% eugenol; EcoSMART Technologies, Inc.), and naturally derived eugenol (99\%) (Citrus and Allied Essences, Ltd., Floral Park, NY). Sprays were applied on 26 Apr. at the $80 \%$ to full bloom (FB) stage of development at $\approx 1421 \mathrm{~L} \cdot \mathrm{ha}^{-1}$. The calculated tree-row volume (TRV) for the test trees was $1477 \mathrm{~L} \cdot \mathrm{ha}^{-1}$. Application rates were ATS at $4 \%$; Matran at $2 \%, 4 \%$, and $6 \%$; and eugenol at $4 \%$ and $6 \%$. Sprays were applied to four four-tree plots in a randomized complete block (RCB) design. A non-thinned control treatment was included for comparison. Total yield ( $\mathrm{kg} /$ tree) and mean fruit weight $(\mathrm{g})$ were determined on two trees per plot at harvest using an Omni Weight Sizer (Durand-Wayland, LaGrange, GA). Crop load density (number of fruit per $\mathrm{cm}^{2}$ trunk cross-sectional area) was calculated from the number of fruit harvested per tree and trunk circumference measurements.

2006 tests. The block of 'Royal Gala'/ M.26 apple trees used in the 2005 test was again selected for treatment in 2006. In addition to a non-thinned control, treatments included: ATS at $6 \%, \mathrm{LS}$ at $3 \%+$ dormant spray oil at $2.5 \mathrm{~mL} \cdot \mathrm{L}^{-1}$, and Matran at $4 \%$ and eugenol at $2 \%$ and $4 \%$ all applied on 19 Apr. at $95 \%$ to $100 \%$ FB. Sprays were applied at $1216 \mathrm{~L} \cdot \mathrm{ha}^{-1}$ to four four-tree plots in a RCB design. The calculated TRV for the block was $1543 \mathrm{~L} \cdot \mathrm{ha}^{-1}$. A second test of bloom thinners was applied in 2006 to a group of 22-year-old 'Ace Spur Delicious'/seedling apple trees. Trees selected had $70 \%$ or more of the available spurs flowering. Airblast treatments were applied to two five-tree plots at 935 $\mathrm{L} \cdot \mathrm{ha}^{-1}$ on $16 \mathrm{Apr}$. when trees were at the $90 \%$ to $100 \%$ FB stage. The calculated mean TRV for the block was $1412 \mathrm{~L} \cdot \mathrm{ha}^{-1}$. Treatments included a non-thinned control, ATS $6 \%$, liquid LS $2 \%$, Matran at $4 \%$ and $6 \%$, and eugenol at $2 \%$ and $4 \%$. At harvest, total yield, fruit weight, and crop load density were determined as described.

2007 tests. Two tests were conducted with bloom thinners on apple. In the first test, Matran was applied at $0 \%, 4 \%, 6 \%$, and $8 \%$ concentrations to 10-year-old 'Ramey York'/ M.26 apple trees on 25 Apr. 2007 at the $60 \%$ to $70 \%$ FB stage. Trees were arranged in three randomly assigned blocks, each containing 12-tree plots that received a treatment. The calculated TRV for the test orchard was $1468 \mathrm{~L} \cdot \mathrm{ha}^{-1}$ and sprays were applied at $\approx 1310 \mathrm{~L} \cdot \mathrm{ha}^{-1}$. At harvest, four trees were randomly selected from each plot and the total yield and mean fruit weight determined using a Durand-Wayland Omni Weight Sizer. Crop load density was determined from total fruit count and trunk size measurements.

In a second test on apple, a group of 5-year-old 'Golden Delicious' apple trees on Budagovsky.9 (B.9) received $0 \%, 2 \%$, $3 \%$, and $4 \%$ eugenol alone or they received $0 \%$ and $4 \%$ eugenol and were manually defoliated on 29 Apr. when trees had reached the FB stage of development. A hand-thinned control was also included for comparison. Trees were arranged in four randomly assigned blocks, each containing three-tree plots that received a spray treatment. The calculated TRV was $1159 \mathrm{~L} \cdot \mathrm{ha}^{-1}$ and sprays were applied at $\approx 1590 \mathrm{~L} \cdot \mathrm{ha}^{-1}$. Hand defoliation was performed on whole trees by physically removing all shoot and spur leaves using scissors to cut the petiole halfway between the point of attachment and the leaf blade. The number of blossoms showing necrotic petals and withered stamens and pistils was determined on two tagged limbs per tree on 2 May $72 \mathrm{~h}$ after treatment. Initial crop load density [fruit per $\mathrm{cm}^{2}$ limb crosssectional area (LCSA)] was determined on the two tagged limbs per tree at the time of hand thinning on 12 June. At maturity, fruit were harvested from tagged limbs, counted, weighed, and sized. Fruit remaining on the tree was counted, weighed, and the diameter of individual fruit recorded.

2008 tests. The 'Royal Gala'/M.26 apple block used in the 2006 tests was again selected for treatments in 2008. In addition to a non-thinned control and a hand-thinned control, spray treatments included a standard post-bloom thinning spray of $100 \mathrm{mg} \cdot \mathrm{L}^{-1}$ 6-BA (MaxCel; Valent BioSciences Corp., Libertyville, IL) plus $2.5 \mathrm{~mL} \cdot \mathrm{L}^{-1}$ carbaryl (Sevin XLR Plus; Bayer CropScience, Research Triangle Park, NC) plus $2.5 \mathrm{~mL} \cdot \mathrm{L}^{-1}$ spray oil, $6.0 \%(\mathrm{v} / \mathrm{v})$ Matratec AG, or 3.0\% eugenol plus $0.62 \mathrm{~mL} \cdot \mathrm{L}^{-1}$ Latron B-1956 (a surfactant with $77 \%$ a.i. as modified phthalic glycerol alkyd resin; Loveland Industries Ltd., Greeley, CO) applied 23 Apr. when trees had reached $95 \%$ to $100 \%$ FB. The postbloom thinner treatment was applied on 13 May when fruit averaged $12.5 \mathrm{~mm}$ in diameter. Hand thinning was performed on 10 June $\approx 49 \mathrm{~d}$ after full bloom (DAFB). The calculated TRV for the block was 2197 $\mathrm{L} \cdot \mathrm{ha}^{-1}$ and sprays were applied at $\approx 1590$ $\mathrm{L} \cdot \mathrm{ha}^{-1}$. Treatments were assigned at random to six three-tree plots in a RCB design. At harvest, fruit were counted, weighed, and sized using the Omni Sort Weight Sizer.

A similar group of treatments was applied in a second trial to 6-year-old 'Cameo'/B.9 and 'Sun Fuji'/B.9 apple trees. In this trial, Matretec AG was applied at $4.0 \%$ and eugenol was applied at $2.0 \%$; otherwise, treatments were identical to those applied to the 'Royal Gala' described. Treatments were applied to four three-tree plots in a RCB. The 'Cameo' trees were estimated to be $\approx 80 \% \mathrm{FB}$ and the 'Sun Fuji' trees at $\approx 95 \%$ to $100 \%$ FB when bloom sprays were applied on 24 Apr. The calculated TRV was 1069 $\mathrm{L} \cdot \mathrm{ha}^{-1}$ and sprays were applied at $\approx 1300$ $\mathrm{L} \cdot \mathrm{ha}^{-1}$. The hand-thinned treatment was performed on 8 June $\approx 45$ DAFB. In late July, some additional fruit were removed from all trees where the potential for limb breakage existed. At maturity, whole trees were harvested and data recorded as described.

\section{Peach}

2003 tests. Spray was applied to 7-yearold 'Redhaven'/'Lovell' peach trees at 414 $\mathrm{kPa}$ when air temperature was $\approx 21{ }^{\circ} \mathrm{C}$ in sunny conditions. Peach tree flowers were $\approx 60 \%$ in bloom when eugenol was applied on 14 Apr. 2003. One tree received one application of each concentration of eugenol 
$(0 \%, 2 \%, 4 \%, 6 \%, 8 \%$, and $10 \%)$. One hundred flowers per tree, uniformly distributed throughout the canopy, were selected for measurement. At $24 \mathrm{~h}$, flowers with wilted pistils and stamens were counted. Surviving fruit were counted 1 and 2 months after application. Peaches were harvested on 7 Aug. 2003 from each treated tree. Total fruit number, weight, and size of individual fruit were measured.

2005 tests. 'Harrow Beauty'/'Lovell' peach trees in the seventh leaf stage were selected for blossom-thinning treatments in 2005. Sprays were applied with a handgun high-pressure sprayer operated at $\approx 689 \mathrm{kPa}$ to wet the bloom. Treatments were applied between 14 and 16 Apr. when trees had reached $90 \%$ to $100 \%$ FB (high winds prevented application of all treatments on the same date). Four materials were applied as bloom thinners at the following rates: ATS, $49 \mathrm{~L} \cdot \mathrm{ha}^{-1}$ (based on a TRV of $1402 \mathrm{~L} \cdot \mathrm{ha}^{-1}$ ); Wilthin at $3.2 \%$; Matran at $2 \%, 4 \%$, and $8 \%$; and eugenol at $2 \%, 4 \%$, and $8 \%$. Treatments were applied to five whole trees in a completely randomized design (CRD). A nonthinned control and a hand-thinned control treatment were included for comparison. The hand-thinned control trees were thinned in early June $\approx 45$ DAFB. Fruit were thinned to $\approx 15$ - to 20 -cm spacing. In late June and early July ( $\approx 70$ to 84 DAFB), all trees, including the control trees, were thinned to remove excess fruit and prevent limb breakage. An attempt was made in this late follow-up hand thinning to space fruit $\approx 15 \mathrm{~cm}$ apart. Crop load was visually estimated with a rating from 1 to 6 in which $1=1 \%$ to $25 \%, 2=26 \%$ to $50 \%, 3=51 \%$ to $100 \%, 4=101 \%$ to $150 \%$, $5=151 \%$ to $200 \%$, and $6=$ greater than $200 \%$ the number of fruit per tree estimated to provide a maximum, marketable crop. Total yield $(\mathrm{kg} / \mathrm{tree})$ was measured at harvest and fruit diameter was determined from a 50-fruit sample per tree.

2006 test. In 2006, bloom thinning treatments were applied to 7-year-old 'Harrow Beauty'/'Lovell' peach trees used in the 2005 previous study. Trees were sprayed on 6 Apr. when they had reached $65 \%$ to $80 \%$ FB. Seven bloom-thinning spray treatments were applied to six to eight trees in a CRD with an airblast sprayer set to deliver $\approx 1216 \mathrm{~L} \cdot \mathrm{ha}^{-1}$. Calculated TRV for the block was 1600 $\mathrm{L} \cdot \mathrm{ha}^{-1}$. The seven treatments included ATS $6 \%$; Matran at $4 \%$ and $6 \%$; and eugenol at $2 \%, 4 \%, 6 \%$, and $8 \%$. A hand-thinned control treatment was included for comparison. Data were collected from a single limb per tree tagged at the time of spray treatment. All trees were hand-thinned to space fruit $\approx 15$ to $20 \mathrm{~cm}$ apart $\approx 50$ DAFB. The number of fruit removed from the tagged limb was recorded at the time of hand thinning. At harvest, the number and weight of fruit removed from the tagged limb were recorded. Limb circumference at the point of origin was recorded at harvest as well as fruit diameter for all harvested fruits on the sample limb.

2007 tests. Eugenol was applied at $0 \%$, $3 \%, 4 \%$, and $5 \%(\mathrm{v} / \mathrm{v})$ on 2 Apr. at a carrier rate of $1337 \mathrm{~L} \cdot \mathrm{ha}^{-1}$ to 6-year-old 'John Boy'/ 'Halford' peaches at $80 \%$ to $90 \%$ FB. The calculated TRV was $1000 \mathrm{~L} \cdot \mathrm{ha}^{-1}$. A separate set of trees receiving $0 \%$ and $5 \%$ eugenol were manually defoliated as described for apple except leaf tissue was removed by pinching out at the point of origin at the node. A hand-thinned control ( $0 \%$ eugenol) was used for comparison. Treatments were applied to four three-tree plots in a RCB design with guard trees between plots within and across rows. Blossom injury was assessed on 20 Apr. and the number of fruit per tree and fruit size recorded at harvest.

2008 tests. Eugenol was applied to 'John Boy'/'Halford' peach trees at various rates $(0 \%$ to $4 \%)$ and stages of bloom development $(20 \% \mathrm{FB}$ to $80 \% \mathrm{FB})$ to six three-tree plots in a RCB. Sprays were applied with the airblast sprayer described previously at $1066 \mathrm{~L} \cdot \mathrm{ha}^{-1}$; calculated TRV was $1000 \mathrm{~L} \cdot \mathrm{ha}^{-1}$. Follow-up hand thinning was performed on all trees at 32 to 34 DAFB and the time required to thin individual trees was recorded. Peaches were harvested in multiple picks as fruit matured. Data for fruit numbers and fruit size were combined on a whole tree basis.

\section{Results}

Apple. In 2003, apple flower injury was apparent at $2 \%$ eugenol and injury increased with increasing concentrations up to $10 \%$ eugenol (Table 1). Little or no leaf or fruit injury was observed, even at the highest concentration on 12 June, $\approx 7$ weeks after application. The effective range for flower thinning and fruit retention appeared to occur between $2 \%$ and $6 \%$ eugenol (Table 1). The total number of apples per tree began to decrease at concentrations of $2 \%$ eugenol and the proportion of apples in the larger size classes increased in trees thinned with eugenol (data not shown).

In 2005, Matran at $6 \%$ reduced crop density by $\approx 48 \%$, yield by $39 \%$, and increased fruit weight by $30 \%$ on 'Royal Gala' apples (Table 2). Eugenol at 4\% increased fruit weight an average of $38 \%$, but yield per tree was reduced by $\approx 74 \%$. Eugenol at $6 \%$ reduced yield to a greater extent $(\approx 88 \%)$ with only $\approx 21 \%$ average increase in fruit weight. Matran at $2 \%$ or ATS had no effect on crop

density, yield, or fruit weight at harvest of 'Royal Gala' in 2005.

In 2006, ATS and LS + oil had no effect on mean yield, fruit weight, or fruit diameter (Table 3). Matran at 4\% reduced yield by $42 \%$ and increased fruit weight by $14 \%$, which was similar to findings in 2005 . Trees treated with eugenol at $2 \%$ had $\approx 28 \%$ lower yields than control trees, which was not significant at $P \leq 0.05$; however, fruit weight was increased $\approx 14 \%$. At the higher rate (4\%), eugenol reduced yield by $79 \%$, but fruit weight was only increased by $18 \%$. The Matran and eugenol at $2 \%$ or $4 \%$ increased fruit diameter over controls. Crop load density for individual treatments was generally a reflection of yield per tree with the three essential oil sprays showing reduced crop load densities compared with the control.

Among the six bloom thinning treatments applied in 2006 to 'Ace Spur Delicious', all spray treatments except $2 \%$ liquid LS reduced yield and increased fruit weight and fruit diameter compared with the control trees (Table 3). Trees sprayed with $6 \%$ ATS, $4 \%$ Matran, or $2 \%$ eugenol produced similar results, reducing yield from $102 \mathrm{~kg} /$ tree to $\approx 60 \mathrm{~kg} /$ tree or slightly less. Matran at $4 \%$ increased fruit weight by $30 \%$, whereas ATS at $6 \%$ or eugenol at $2 \%$ only increased fruit weight by $15 \%$ or $11 \%$, respectively, over control fruit. Both $6 \%$ Matran and 4\% eugenol resulted in excessive yield reduction $(73 \%$ and $86 \%$, respectively) on 'Ace Spur Delicious'. The 4\% eugenol treatment increased average fruit weight from $157 \mathrm{~g}$ (control treatment) to $230 \mathrm{~g}$, but the size increase was offset by the severe reduction in yield.

In 2007, a thinning response was observed on 'Ramey York' apple with increasing rates of Matran (Table 4). There was a significant reduction in crop load as the rate of Matran increased from $0 \%$ to $8 \%$. Individual fruit weight increased $62 \%$ and yield per tree declined by $\approx 32 \%$ as the rate of Matran increased up to an $8 \%$ rate of application compared with the untreated control trees (Table 4). Eugenol applied at FB to 5-yearold 'Golden Delicious'/B.9 apple trees at 2\%, $3 \%$, or $4 \%(\mathrm{v} / \mathrm{v})$ overthinned (Table 5$)$. Fruit diameter and weight were increased on trees receiving a $2 \%$ and a $4 \%$ eugenol bloom spray; however, the $4 \%$ rate almost eliminated

Table 1. Blossom thinning and fruit retention on 'Ace Spur Delicious'/M.7 apple trees and 'Redhaven'/ 'Lovell' peach trees treated with an essential oil, eugenol, in Spring 2003.

\begin{tabular}{|c|c|c|c|c|c|c|}
\hline \multirow{2}{*}{$\begin{array}{l}\text { Eugenol }{ }^{\mathrm{z}} \\
(\%, \mathrm{v} / \mathrm{v})\end{array}$} & \multicolumn{2}{|c|}{ Flowers injured ${ }^{\mathrm{y}}$} & \multicolumn{2}{|c|}{ Fruit 1 month after treatment ${ }^{x}$} & \multicolumn{2}{|c|}{ Fruit 2 months after treatment ${ }^{x}$} \\
\hline & Apple (\%) & Peach (\%) & Apple (\%) & Peach $(\%)$ & Apple (\%) & Peach $(\%)$ \\
\hline 0 & 0 & 0 & 19 & 39 & 19 & 27 \\
\hline 2 & 7 & 15 & 10 & 20 & 10 & 6 \\
\hline 4 & 32 & 38 & 8 & 20 & 6 & 5 \\
\hline 6 & 57 & 50 & 1 & 22 & 2 & 5 \\
\hline 8 & 68 & 61 & 2 & 17 & 2 & 3 \\
\hline 10 & 73 & 69 & 1 & 5 & 0 & 5 \\
\hline
\end{tabular}

${ }^{\mathrm{z} E u g e n o l}$ 99\% a.i. from Citrus and Allied Essences, Ltd., Floral Park, NY.

${ }^{y}$ Apple flower survival was counted for 100 flower clusters that were selected before the essential oil was applied. Peach flower survival for 100 flowers selected before essential oil application.

${ }^{\mathrm{x}}$ Apple fruit retention was determined by counting fruit from the same 100 flower clusters selected before the essential oil application; five fruit per cluster. Peach fruit retention was counted for the 100 flowers selected before essential oil application. 


\begin{tabular}{|c|c|c|c|c|c|c|c|c|}
\hline \multirow[b]{3}{*}{ Treatment } & \multirow[b]{3}{*}{$\begin{array}{l}\text { Chemical } \\
\text { concn }(\%)\end{array}$} & \multirow[b]{3}{*}{$\begin{array}{c}\text { Eugenol } \\
\text { concn }(\%)\end{array}$} & \multirow{2}{*}{\multicolumn{3}{|c|}{ Royal Gala/M.26 }} & \multicolumn{3}{|c|}{ Harrow Beauty/Lovell } \\
\hline & & & & & & \multirow{2}{*}{$\begin{array}{l}\text { Crop load } \\
\text { estimate } \\
(1-6)^{\mathrm{y}}\end{array}$} & \multirow[b]{2}{*}{$\begin{array}{c}\text { Yield } \\
(\mathrm{kg} / \text { tree })\end{array}$} & \multirow{2}{*}{$\begin{array}{l}\text { Fruit } \\
\text { diam } \\
(\mathrm{cm})\end{array}$} \\
\hline & & & $\begin{array}{c}\text { Crop density } \\
\text { (fruit } / \mathrm{cm}^{2} \mathrm{TCSA}^{\mathrm{z}} \text { ) }\end{array}$ & $\begin{array}{c}\text { Yield } \\
(\mathrm{kg} / \text { tree })\end{array}$ & $\begin{array}{l}\text { Fruit } \\
\text { wt (g) }\end{array}$ & & & \\
\hline Control & 0 & 0 & $8.6 \mathrm{a}^{\mathrm{x}}$ & $81 \mathrm{a}$ & $107 \mathrm{~d}$ & $5.6 \mathrm{a}$ & $81 \mathrm{ab}$ & $6.3 \mathrm{c}$ \\
\hline Hand thinned & 0 & 0 & $\mathrm{NA}^{\mathrm{w}}$ & NA & NA & $2.6 \mathrm{ef}$ & $84 \mathrm{ab}$ & $6.6 \mathrm{bc}$ \\
\hline $\operatorname{ATS}^{v}$ & - & 0 & $7.4 \mathrm{a}$ & $80 \mathrm{a}$ & $120 \mathrm{~cd}$ & $3.8 \mathrm{~cd}$ & $50 \mathrm{c}$ & $6.6 \mathrm{bc}$ \\
\hline Wilthin & 3.2 & 0 & NA & NA & NA & $3.1 \mathrm{de}$ & $33 \mathrm{c}$ & $7.0 \mathrm{a}$ \\
\hline Matran EC & 2.0 & 0.8 & $7.7 \mathrm{a}$ & $72 \mathrm{abc}$ & $119 \mathrm{~cd}$ & $5.4 \mathrm{a}$ & $84 \mathrm{ab}$ & $6.6 \mathrm{bc}$ \\
\hline Matran EC & 4.0 & 1.6 & $4.9 \mathrm{bc}$ & $53 \mathrm{bc}$ & $118 \mathrm{~cd}$ & $4.8 \mathrm{ab}$ & $96 \mathrm{a}$ & $6.6 \mathrm{bc}$ \\
\hline Matran EC & 6.0 & 2.4 & $4.5 \mathrm{c}$ & $49 \mathrm{c}$ & $139 \mathrm{ab}$ & NA & NA & NA \\
\hline Matran EC & 8.0 & 3.2 & NA & NA & NA & $4.4 \mathrm{bc}$ & $84 \mathrm{ab}$ & $6.8 \mathrm{ab}$ \\
\hline Eugenol & 2.0 & 2.0 & NA & NA & NA & $4.2 \mathrm{bc}$ & $61 \mathrm{bc}$ & $6.6 \mathrm{bc}$ \\
\hline Eugenol & 4.0 & 4.0 & $1.5 \mathrm{~d}$ & $21 \mathrm{~d}$ & $148 \mathrm{a}$ & $3.2 \mathrm{de}$ & $45 \mathrm{c}$ & $7.0 \mathrm{a}$ \\
\hline Eugenol & 6.0 & 6.0 & $1.0 \mathrm{~d}$ & $10 \mathrm{~d}$ & $129 \mathrm{bc}$ & NA & NA & NA \\
\hline$\underline{\text { Eugenol }}$ & 8.0 & 8.0 & NA & NA & NA & $2.1 \mathrm{f}$ & $37 \mathrm{c}$ & $7.0 \mathrm{a}$ \\
\hline
\end{tabular}

${ }^{\mathrm{z} T C S A}=$ trunk cross-sectional area

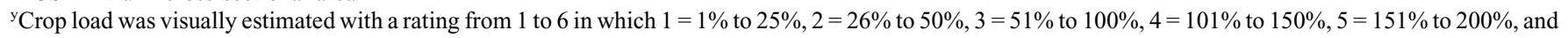
$6=200 \%$ or greater the number of fruit per tree estimated to provide a maximum, marketable crop.

${ }^{x}$ Means separation within columns by Duncan's new multiple range test $(P \leq 0.05)$.

wN $=$ treatment not applied.

${ }^{\mathrm{v}} \mathrm{ATS}=$ ammonium thiosulfate. Applied at a rate of $49 \mathrm{~L} \cdot \mathrm{ha}^{-1}$ in peach.

Table 3. Response of 'Royal Gala'/M.26 and 'Ace Spur Delicious'/seedling apple trees to bloom thinners in 2006.

\begin{tabular}{|c|c|c|c|c|c|}
\hline \multirow[b]{2}{*}{ Thinner treatment ${ }^{z}$} & \multirow[b]{2}{*}{ Concn $(\%)^{y}$} & \multirow{2}{*}{$\begin{array}{c}\text { Crop load } \\
\text { density (fruit } / \mathrm{cm}^{2} \\
\text { TCSA }^{\mathrm{x}} \text { ) }\end{array}$} & \multicolumn{3}{|c|}{ Mean fruit } \\
\hline & & & Wt (g) & $\operatorname{Diam}(\mathrm{cm})$ & Yield (kg/tree) \\
\hline \multicolumn{6}{|l|}{ Royal Gala } \\
\hline Control & & $9.8 \mathrm{a}^{\mathrm{w}}$ & $117 \mathrm{c}$ & $6.53 \mathrm{c}$ & $100.7 \mathrm{ab}$ \\
\hline $\operatorname{ATS}^{v}$ & 6.0 & $8.6 \mathrm{ab}$ & $123 \mathrm{bc}$ & $6.70 \mathrm{abc}$ & $79.8 \mathrm{bc}$ \\
\hline $\mathrm{LS}+$ oil $^{\mathrm{u}}$ & $3.0+0.025$ & $9.0 \mathrm{a}$ & $120 \mathrm{c}$ & $6.60 \mathrm{bc}$ & $113.1 \mathrm{a}$ \\
\hline Matran EC & 4.0 & $4.6 \mathrm{c}$ & $134 \mathrm{ab}$ & $6.88 \mathrm{a}$ & $58.0 \mathrm{c}$ \\
\hline Eugenol & 2.0 & $5.6 \mathrm{bc}$ & $133 \mathrm{ab}$ & $6.91 \mathrm{a}$ & $72.9 \mathrm{bc}$ \\
\hline Eugenol & 4.0 & $1.4 \mathrm{~d}$ & $138 \mathrm{a}$ & $6.81 \mathrm{ab}$ & $21.1 \mathrm{~d}$ \\
\hline$P$ & & 0.0001 & 0.0043 & 0.0049 & 0.0001 \\
\hline \multicolumn{6}{|l|}{ Ace Spur Delicious } \\
\hline Control & & $2.4 \mathrm{a}$ & $157 \mathrm{e}$ & $7.00 \mathrm{~d}$ & $101.6 \mathrm{a}$ \\
\hline ATS & 6.0 & $1.2 \mathrm{~b}$ & $181 \mathrm{c}$ & $7.39 \mathrm{c}$ & $61.6 \mathrm{~b}$ \\
\hline LS & 2.0 & $2.4 \mathrm{a}$ & $161 \mathrm{de}$ & $7.18 \mathrm{~cd}$ & $110.6 \mathrm{a}$ \\
\hline Matran EC & 4.0 & $0.8 \mathrm{bc}$ & $203 \mathrm{~b}$ & $7.71 \mathrm{~b}$ & $49.4 \mathrm{~b}$ \\
\hline Matran EC & 6.0 & $0.4 \mathrm{~cd}$ & $204 \mathrm{~b}$ & $7.83 \mathrm{~b}$ & $27.2 \mathrm{c}$ \\
\hline Eugenol & 2.0 & $1.3 \mathrm{~b}$ & $175 \mathrm{~cd}$ & $7.34 \mathrm{c}$ & $60.5 \mathrm{~b}$ \\
\hline Eugenol & 4.0 & $0.2 \mathrm{~d}$ & $230 \mathrm{a}$ & $8.07 \mathrm{a}$ & $14.4 \mathrm{c}$ \\
\hline$P$ & & 0.0001 & 0.0001 & 0.0001 & 0.0001 \\
\hline
\end{tabular}

${ }^{\mathrm{z}}$ All sprays applied with an airblast sprayer.

${ }^{\mathrm{y}}$ In water as volume/volume.

${ }^{\mathrm{x}} \mathrm{TCSA}=$ trunk cross-sectional area.

${ }^{w}$ Means separation within columns for cultivars by Duncan's new multiple range test $(P \leq 0.05)$.

${ }^{\mathrm{v}} \mathrm{ATS}=$ ammonium thiosulfate.

"Liquid lime sulfur plus dormant superior spray oil.

Table 4. Effect of Matran EC (50\% clove oil) applied as a bloom thinner on 'Ramey York'/M.26 apple trees in 2007.

\begin{tabular}{lcccc}
\hline $\begin{array}{l}\text { Thinner } \\
\text { treatment }\end{array}$ & $\begin{array}{c}\text { Concn } \\
(\%, \mathrm{v} / \mathrm{v})\end{array}$ & $\begin{array}{c}\text { Crop load density } \\
\left(\text { fruit } / \mathrm{cm}^{2} \mathrm{TCSA}^{\mathrm{y}}\right)\end{array}$ & Mean fruit wt $(\mathrm{g})$ & Yield (kg/tree) \\
\hline Control & 0 & $8.8 \mathrm{a}^{\mathrm{x}}$ & $123 \mathrm{c}$ & $117.3 \mathrm{a}$ \\
Matran EC & 4.0 & $6.3 \mathrm{~b}$ & $172 \mathrm{~b}$ & $97.7 \mathrm{ab}$ \\
Matran EC & 6.0 & $3.9 \mathrm{c}$ & $179 \mathrm{~b}$ & $76.4 \mathrm{~b}$ \\
Matran EC & 8.0 & $3.3 \mathrm{c}$ & $199 \mathrm{a}$ & $79.1 \mathrm{~b}$ \\
$P^{\mathrm{w}}$ & & 0.0001 & 0.0001 & 0.0010 \\
$r^{2}$ & & 0.6984 & 0.5968 & 0.2789 \\
Significance $^{\mathrm{v}}$ & & $\mathrm{L}^{* * *}$ & $\mathrm{~L}^{* * *}$ & $\mathrm{~L}^{* * *}$ \\
\hline
\end{tabular}

${ }^{\mathrm{z}}$ All sprays applied with airblast sprayer at $1309 \mathrm{~L} \cdot \mathrm{ha}^{-1}$ at $60 \%$ to $70 \%$ full bloom.

${ }^{\mathrm{y}} \mathrm{TCSA}=$ trunk cross-sectional area.

${ }^{\mathrm{x}}$ Means separation within columns by Duncan's new multiple range test $(P \leq 0.05)$.

${ }^{\text {w}}$ Probability for model.

'Linear regression; $* * * * *$ significant at $P \leq 0.01$ or 0.001 , respectively.

the crop. Hand defoliation at bloom time caused complete fruit abscission (Table 5).

In 2008 , a single rate of $50 \%$ clove oil (Matratec AG) $(6 \%)$ or eugenol $(3 \%)+$
Latron B-1956 applied at $95 \%$ to $100 \% \mathrm{FB}$ were equally effective in reducing crop load and increasing fruit weight on 'Royal Gala' apple trees (Fig. 2). Results did not differ from the post-bloom spray of 6-BA (MaxCel) + carbaryl (Sevin XLR Plus) + oil. The bloom-thinning sprays reduced crop load to a greater extent than hand thinning, but fruit weight was greater for the bloom-thinning sprays compared with the hand-thinned treatment or the non-thinned control. All thinning treatments reduced crop load, but the thinning achieved with clove oil at $6 \%$ and eugenol + Latron B-1956 at 3\% was excessive.

The single rate of eugenol + Latron B-1956 (2\%) or clove oil (Matratec AG, 4\%) each thinned 'Cameo' and 'Sun Fuji' apple trees to a similar level as the traditional post-bloom thinner 6-BA (MaxCel) + carbaryl + oil (Table 6). Crop load on 'Cameo' was equal to that achieved with hand thinning. However, hand-thinned 'Sun Fuji' had a greater crop load but smaller fruit (weight and diameter) than the chemical thinner treatments. Hand-thinned 'Sun Fuji' had a reduced crop load compared with the nonthinned control, but fruit size was equal to that of the non-thinned control.

Peach. In 2003, within $1 \mathrm{~h}$ of application of the essential oil, peach flowers began to appear bleached and leaf tips developed necrotic lesions. Injury was apparent at 2\% and increased proportionately as concentrations increased to $10 \%$, which had notable injury (Table 1). Little injury to peach flowers was observed at concentrations below $1.5 \%$ (data not shown). By 4 to 5 weeks after application, little injury could be observed on peach trees treated at the highest concentration, $10 \%$, but few fruit remained on the tree at this concentration. The effective rate for flower thinning and fruit retention was between $2 \%$ and $6 \%$ eugenol (Table 1 ). No fruit or leaf injury was seen on 12 June 2003 at the $6 \%$ concentration. The total number and weight of peaches per tree began to decrease at concentrations of $2 \%$ essential oil and average fruit weight generally was higher in thinned peach trees (data not shown).

Four bloom spray treatments in 2005 reduced the yield of 'Harrow Beauty' peach trees compared with the control trees (hand-thinned 
Table 5. Response of 5-year-old 'Golden Delicious'/Budagovsky 9 (B.9) apple trees to eugenol blossom thinner and hand defoliation treatments in 2007.

\begin{tabular}{|c|c|c|c|c|c|c|c|c|}
\hline \multirow[b]{3}{*}{$\begin{array}{l}\text { Thinning } \\
\text { treatment }^{\mathrm{z}}\end{array}$} & \multirow[b]{3}{*}{$\begin{array}{l}\text { Concn } \\
(\%, v / v)\end{array}$} & \multirow[b]{3}{*}{$\begin{array}{c}\text { Hand } \\
\text { defoliated }^{\mathrm{y}}\end{array}$} & \multirow[b]{3}{*}{$\begin{array}{l}\text { Blossoms } \\
\text { injured }^{\mathrm{x}}(\%)\end{array}$} & \multicolumn{2}{|c|}{ Crop load ${ }^{\mathrm{w}}$} & \multirow{2}{*}{\multicolumn{3}{|c|}{ Fruit }} \\
\hline & & & & Initial & Harvest & & & \\
\hline & & & & $\begin{array}{c}\left(\text { fruit } / \mathrm{cm}^{2}\right. \\
\mathrm{LCSA}^{\mathrm{v}} \text { ) }\end{array}$ & $\begin{array}{c}\left(\text { fruit } / \mathrm{cm}^{2}\right. \\
\text { LCSA }^{v} \text { ) }\end{array}$ & $\begin{array}{c}\text { Yield } \\
\text { (kg/tree) }\end{array}$ & $\begin{array}{l}\text { Diam } \\
(\mathrm{cm})\end{array}$ & $\begin{array}{l}\mathrm{Wt} \\
(\mathrm{g})\end{array}$ \\
\hline Control & 0 & No & $0 \mathrm{c}^{\mathrm{u}}$ & $11.2 \mathrm{a}$ & $7.7 \mathrm{a}$ & $24.2 \mathrm{a}$ & $5.92 \mathrm{~b}$ & $90 \mathrm{~b}$ \\
\hline Control & 0 & Yes & $0 \mathrm{c}$ & $2.3 \mathrm{bc}$ & $0 \mathrm{c}$ & $0 \mathrm{~b}$ & - & - \\
\hline $\begin{array}{l}\text { Hand } \\
\text { thinned }\end{array}$ & 0 & No & $0 \mathrm{c}$ & $7.6 \mathrm{ab}$ & $4.4 \mathrm{~b}$ & $22.7 \mathrm{a}$ & $6.54 \mathrm{ab}$ & $103 \mathrm{~b}$ \\
\hline Eugenol & 2.0 & No & $68 \mathrm{~b}$ & $5.1 \mathrm{bc}$ & $1.3 \mathrm{c}$ & $5.1 \mathrm{~b}$ & $7.06 \mathrm{a}$ & $154 \mathrm{a}$ \\
\hline Eugenol & 3.0 & No & $74 \mathrm{~b}$ & $0 \mathrm{c}$ & $0 \mathrm{c}$ & $0.4 \mathrm{~b}$ & $6.69 \mathrm{ab}$ & $152 \mathrm{ab}$ \\
\hline Eugenol & 4.0 & No & $88 \mathrm{ab}$ & $0 \mathrm{c}$ & $0 \mathrm{c}$ & $0.2 \mathrm{~b}$ & $7.50 \mathrm{a}$ & $168 \mathrm{a}$ \\
\hline Eugenol & 4.0 & Yes & $95 \mathrm{a}$ & $0 \mathrm{c}$ & $0 \mathrm{c}$ & $0 \mathrm{~b}$ & - & - \\
\hline
\end{tabular}

${ }^{\mathrm{z}}$ Eugenol sprays applied with airblast sprayer at $1590 \mathrm{~L} \cdot \mathrm{ha}^{-1}$ at full bloom (29 Apr. 2007).

y30 Apr. 2007.

${ }^{\mathrm{x}}$ Necrotic petals and withered stamens and pistils.

winitial crop load, 2 June; harvest, 24 Sept. 2007.

${ }^{\vee} \mathrm{LCSA}=$ limb cross-sectional area.

${ }^{u}$ Means separation within columns by SAS PROC MIXED $(P \leq 0.05)$ except for fruit weight $(P \leq 0.10)$.

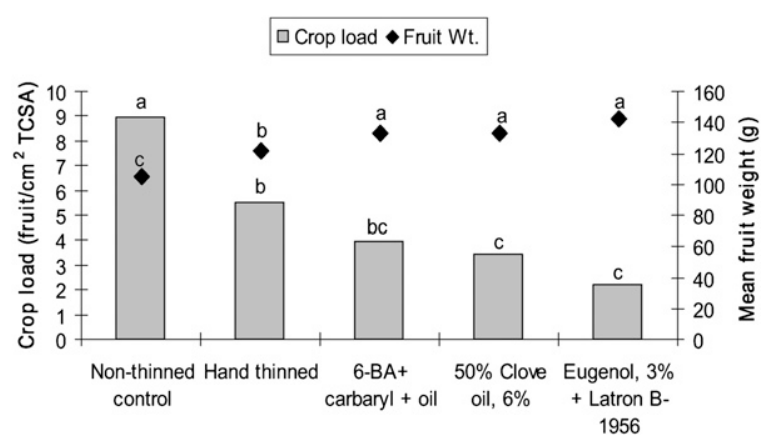

Fig. 2. Response of 'Royal Gala'/M.26 apple trees to bloom and post-bloom thinning in 2008. Clove oil, $50 \%$ (Matratec AG) and eugenol + Latron B-1956 bloom sprays applied 23 Apr. at 95-100\% full bloom. Postbloom thinner [ 6-BA (MaxCel) + carbaryl (Sevin XLR Plus) + oil] applied 13 May when fruit averaged $12.5 \mathrm{~mm}$ diameter. Hand thinning on 10 June about 49 days after full bloom. Mean Separation within bars or on diamonds by Duncan's new multiple range test, $P \leq 0.05$ after SAS Proc MIXED.

Table 6. Effect of bloom thinners or a post-bloom thinner on crop load and fruit size in 6-year-old 'Cameo'/ Budagovsky 9 (B.9) and 'Sun Fuji'/B.9 apple trees in 2008.

\begin{tabular}{|c|c|c|c|c|c|c|}
\hline \multirow[b]{2}{*}{ Treatment $^{2}$} & \multicolumn{2}{|c|}{ Crop load (fruit $/ \mathrm{cm}^{2} \mathrm{TCSA}^{\mathrm{y}}$ ) } & \multicolumn{2}{|c|}{ Mean fruit wt. (g) } & \multicolumn{2}{|c|}{ Mean fruit diam $(\mathrm{cm})$} \\
\hline & Cameo & Fuji & Cameo & Fuji & Cameo & Fuji \\
\hline Non-thinned control & $17.7 \mathrm{a}^{\mathrm{x}}$ & $22.7 \mathrm{a}$ & $135 \mathrm{~b}$ & $101 \mathrm{c}$ & $6.98 \mathrm{c}$ & $6.19 \mathrm{c}$ \\
\hline Hand-thinned control & $9.7 \mathrm{~b}$ & $13.7 \mathrm{~b}$ & $162 \mathrm{a}$ & $117 \mathrm{c}$ & $7.30 \mathrm{bc}$ & $6.46 \mathrm{c}$ \\
\hline $\begin{array}{c}\text { 6-BA, } 100 \mathrm{ppm}+\text { carbaryl, } \\
1 \mathrm{qt} / 100+\text { oil, } 1 \mathrm{qt} / 100\end{array}$ & $7.5 \mathrm{~b}$ & $6.2 \mathrm{~d}$ & $185 \mathrm{a}$ & $204 \mathrm{a}$ & $7.74 \mathrm{a}$ & $7.71 \mathrm{a}$ \\
\hline Clove oil, 4\% (v/v) & $7.1 \mathrm{~b}$ & $9.7 \mathrm{c}$ & $178 \mathrm{a}$ & $148 \mathrm{~b}$ & 7.61ab & $7.15 \mathrm{~b}$ \\
\hline $\begin{array}{l}\text { Eugenol, } 2 \%(\mathrm{v} / \mathrm{v})+\text { Latron } \\
\text { B-1956, } 0.5 \mathrm{pt} / 100\end{array}$ & $7.5 \mathrm{~b}$ & $7.8 \mathrm{~cd}$ & $186 \mathrm{a}$ & $160 \mathrm{~b}$ & $7.69 \mathrm{ab}$ & $7.25 \mathrm{~b}$ \\
\hline$P$ & 0.0001 & 0.0001 & 0.0022 & 0.0001 & 0.0017 & 0.0001 \\
\hline
\end{tabular}

${ }^{\mathrm{z}}$ 6-BA [6-benzyladenine as MaxCel (Valent BioSciences, Libertyville, IL)] + carbaryl [Sevin XLR Plus (Bayer CropScience, Research Triangle Park, NC)] + oil (dormant spray oil) applied 14 May at 10-- to 12$\mathrm{mm}$ stage; clove oil (50\%) [as Matratec AG (ClawEl Specialty Products, Pleasant Plain, IL)] and eugenol (99\%, Citrus and Allied Essences, Ltd., Floral Park, NY) applied 24 Apr.; Latron B-1956 (Loveland Industries Ltd., Greeley, $\mathrm{CO}$ ) is a surfactant. Hand thinning applied $\approx 45 \mathrm{~d}$ after full bloom.

${ }^{\mathrm{y}} \mathrm{TCSA}=$ trunk cross-sectional area.

${ }^{\mathrm{x}}$ Means separation within columns by Duncan's new multiple range test $(P \leq 0.05)$.

$\approx 70$ DAFB) and the hand-thinned control trees: ATS, Wilthin, and eugenol at $4 \%$ and $8 \%$ (Table 2). Fruit diameter was increased in three of the treatments: Wilthin, $4 \%$ eugenol, and $8 \%$ eugenol. Based on tree spacing, the calculated yield per ha for the three treatments ranged from a high of 699 boxes (21.7 $\mathrm{kg} / \mathrm{box}$ ) for the $4 \%$ eugenol treatment to a low of 509 boxes for Wilthin-treated trees. All other treatments resulted in fruit diameters below the desired 6.98-cm size. Matran at the three rates used in this test produced yields than the hand-thinned controls, but it averaged $\approx 7 \%$ larger $(7.19 \mathrm{~cm}$ versus $6.72 \mathrm{~cm}$ for controls) and was above the desired size of $6.98 \mathrm{~cm}$. Fewer fruit were removed during the follow-up hand-thinning operation on the trees treated with $6 \%$ Matran than on the hand-thinned control trees, but crop load and fruit diameter did not differ from the handthinned control trees at harvest. Crop load was significantly less and fruit size greater on trees sprayed with $6 \%$ ATS or $8 \%$ eugenol compared with the hand-thinned control trees. Trees sprayed with these two treatments required significantly less follow-up hand thinning than the hand-thinned control trees. Trees treated with $6 \%$ ATS had a mean crop load of only 0.3 fruit $/ \mathrm{cm}^{2}$ LCSA compared with 2.8 fruit $/ \mathrm{cm}^{2}$ LCSA on the hand-thinned control trees. ATS treatment produced the largest diameter fruits with a mean of $7.8 \mathrm{~cm}$. Hand-thinned control fruit averaged $6.7 \mathrm{~cm}$ diameter, less than the desirable $6.98-\mathrm{cm}$ fruit size.

In 2007, eugenol concentrations of $3 \%$, $4 \%$, and $5 \%$ thinned peaches and increased fruit diameter compared with the non-thinned control. However, all three concentrations of eugenol resulted in overthinning (Fig. 3). Bloom damage on trees treated with eugenol ranged from $82 \%$ at $3 \%$ spray to $99 \%$ for trees sprayed at the $5 \%$ level. Unlike in apple, defoliation had no effect on fruit abscission in peach (data not shown).

In 2008, single and split applications of eugenol at $1 \%$ to $4 \%$ significantly reduced crop load, follow-up hand-thinning time, and yield and increased average fruit diameter compared with a non-thinned control (Table 8 ). Single applications of $3 \%$ or $4 \%$ or split applications totaling $4 \%$ or $5 \%$ appeared to overthin (Table 8). Split applications of low rates of eugenol $(1 \%$ and $2 \%)$ provided desirable thinning.

\section{Discussion}

Weather patterns in the mid-Atlantic region during the normal apple and peach bloom period (late March through April) are extremely variable and day-to-day conditions (temperature, precipitation, sun, cloud cover, wind, etc.) can be quite volatile, unpredictable, and present a significant challenge for the orchardist in their attempt to apply sprays at defined phenological stages of development. Unexpected high temperatures one day can lead to dramatic changes in bloom development within an 8 - to $24-\mathrm{h}$ period. This is particularly true in the case of peach. For these reasons as well as resource limitations, no attempt was made to apply an identical group of treatments each year over the life of the study. However, sufficient similarities in treatment concentrations and timing have been included in this study to draw conclusions regarding the efficacy of eugenol or eugenol-based materials as bloom thinners.

Thinning is needed to obtain good marketable size fruit. These experiments evaluated a novel thinning agent, eugenol, and an essential oil-based plant growth regulator 
Table 7. Response of 'Harrow Beauty'/'Lovell' peach trees to chemical bloom thinners and hand thinning in 2006.

\begin{tabular}{lccccc}
\hline $\begin{array}{l}\text { Thinner } \\
\text { treatment }\end{array}$ & $\begin{array}{c}\text { Concn } \\
(\%)^{\mathrm{y}}\end{array}$ & $\begin{array}{c}\text { No. fruit removed } \\
\text { by hand thinning }\end{array}$ & $\begin{array}{c}\text { Yield } \\
(\mathrm{kg} / \text { limb })\end{array}$ & $\begin{array}{c}\text { Fruit } \\
\text { diam }(\mathrm{cm})\end{array}$ & $\begin{array}{c}\text { Fruit } / \mathrm{cm}^{2} \\
\text { LCSA }^{\mathrm{w}}\end{array}$ \\
\hline Control $^{\mathrm{x}}$ & 0 & $232 \mathrm{a}^{\mathrm{v}}$ & $14.2 \mathrm{a}$ & $6.72 \mathrm{~cd}$ & $2.8 \mathrm{a}$ \\
ATS $^{\mathrm{u}}$ & 6.0 & $12 \mathrm{c}$ & $3.1 \mathrm{c}$ & $7.79 \mathrm{a}$ & $0.3 \mathrm{c}$ \\
Matran EC & 4.0 & $220 \mathrm{ab}$ & $11.4 \mathrm{ab}$ & $6.45 \mathrm{~cd}$ & $2.5 \mathrm{ab}$ \\
Matran EC & 6.0 & $104 \mathrm{bc}$ & $4.9 \mathrm{bc}$ & $6.35 \mathrm{~d}$ & $2.1 \mathrm{abc}$ \\
Eugenol & 2.0 & $120 \mathrm{abc}$ & $8.6 \mathrm{abc}$ & $6.74 \mathrm{~cd}$ & $2.4 \mathrm{ab}$ \\
Eugenol & 4.0 & $127 \mathrm{abc}$ & $9.5 \mathrm{abc}$ & $7.00 \mathrm{bcd}$ & $2.0 \mathrm{abc}$ \\
Eugenol & 6.0 & $76 \mathrm{c}$ & $5.5 \mathrm{bc}$ & $7.19 \mathrm{abc}$ & $1.4 \mathrm{abc}$ \\
Eugenol & 8.0 & $33 \mathrm{c}$ & $5.0 \mathrm{bc}$ & $7.65 \mathrm{ab}$ & $1.0 \mathrm{bc}$
\end{tabular}

${ }^{2}$ All sprays applied with airblast sprayer at $1216 \mathrm{~L} \cdot \mathrm{ha}^{-1}$ at $65 \%$ to $85 \%$ full bloom. Control trees handthinned $\approx 50 \mathrm{~d}$ after full bloom

${ }^{\mathrm{y}}$ In water as volume/volume.

${ }^{\mathrm{x}}$ Trees hand thinned $\approx 50 \mathrm{~d}$ after full bloom.

${ }^{\mathrm{w}} \mathrm{LCSA}=$ limb cross-sectional area.

'Means separation within columns by Duncan's new multiple range test $(P \leq 0.05)$.

"ATS = ammonium thiosulfate.
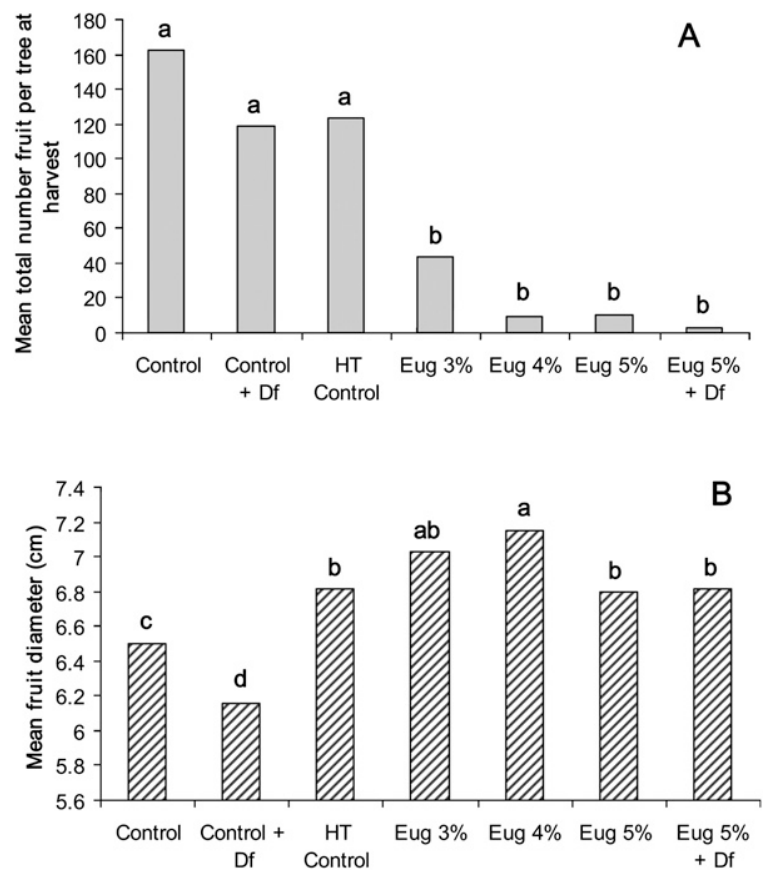

Fig. 3. Effect of eugenol as a bloom thinner with and without hand defoliation in 2007 on A) fruit numbers per tree $(P \leq 0.10)$ and B) fruit diameter $(P \leq 0.05)$ in 6-year-old 'John Boy'/'Halford' peach trees. Sprays applied with airblast sprayer on 2 Apr. 2007 at $80-90 \%$ full bloom at about $1309 \mathrm{~L} / \mathrm{ha}$.

Table 8. Response of 'John Boy'/'Halford' peach trees to eugenol as a bloom thinner applied at various concentrations and time of bloom development on crop load, follow-up hand-thinning time, yield, and fruit size in 2008 .

\begin{tabular}{|c|c|c|c|c|}
\hline $\begin{array}{l}\text { Treatment }{ }^{\mathrm{z}}(\% \text { eugenol - bloom stage }) \\
\left(\text { boxes } / \mathrm{ha}^{\mathrm{x}}\right)\end{array}$ & $\begin{array}{c}\text { Crop load } \\
\text { (fruit/ } \mathrm{cm}^{2} \\
\text { TCSA }^{y} \text { ) }\end{array}$ & $\begin{array}{l}\text { Hand thinning } \\
\text { time }(\mathrm{min} / \text { tree })\end{array}$ & $\begin{array}{c}\text { Fruit } \\
\operatorname{diam}(\mathrm{cm})\end{array}$ & $\begin{array}{c}\text { Yield } \\
\left.\text { (boxes/ha } / \mathrm{ha}^{\mathrm{x}}\right)\end{array}$ \\
\hline Control & $10.5 \mathrm{a}^{\mathrm{w}}$ & $19.7 \mathrm{a}$ & $6.72 \mathrm{~d}$ & $650 \mathrm{a}$ \\
\hline $2.0 \%-80 \% \mathrm{FB}$ & $5.2 \mathrm{~b}$ & $6.2 \mathrm{c}$ & $7.13 \mathrm{c}$ & $398 \mathrm{~b}$ \\
\hline $3.0 \%-80 \% \mathrm{FB}$ & $0.5 \mathrm{e}$ & $0.8 \mathrm{~d}$ & $7.52 \mathrm{ab}$ & $163 \mathrm{c}$ \\
\hline $4.0 \%-80 \% \mathrm{FB}$ & 1.2 cde & $2.4 \mathrm{~cd}$ & $7.53 \mathrm{ab}$ & $237 \mathrm{bc}$ \\
\hline $4.0 \%-50 \% \mathrm{FB}$ & $1.0 \mathrm{de}$ & $1.4 \mathrm{~d}$ & $7.63 \mathrm{a}$ & $269 \mathrm{bc}$ \\
\hline $2.0 \%-20 \% \mathrm{FB}$ and $80 \% \mathrm{FB}$ & 1.9 cde & $1.6 \mathrm{~d}$ & $7.50 \mathrm{ab}$ & $301 \mathrm{bc}$ \\
\hline $2.0 \%-50 \% \mathrm{FB}$ and $80 \% \mathrm{FB}$ & $2.2 \mathrm{~cd}$ & $3.6 \mathrm{~cd}$ & $7.33 \mathrm{bc}$ & $339 \mathrm{bc}$ \\
\hline $1.0 \%-20 \% \mathrm{FB}$ and $2.0 \%-80 \% \mathrm{FB}$ & $5.5 \mathrm{~b}$ & $11.1 \mathrm{~b}$ & $7.20 \mathrm{c}$ & $578 \mathrm{a}$ \\
\hline $1.0 \%-20 \% \mathrm{FB}$ and $3.0 \%-80 \% \mathrm{FB}$ & $2.6 \mathrm{c}$ & $4.4 \mathrm{~cd}$ & $7.32 \mathrm{bc}$ & $398 \mathrm{~b}$ \\
\hline $2.0 \%-20 \% \mathrm{FB}$ and $3.0 \%-80 \% \mathrm{FB}$ & $1.5 \mathrm{cde}$ & $2.4 \mathrm{~cd}$ & $7.47 \mathrm{ab}$ & $252 \mathrm{bc}$ \\
\hline
\end{tabular}

${ }^{2}$ Eugenol treatments applied with a Durand-Wayland AF100-32 Model 3-pt. hitch airblast sprayer. Treatment identification is \% eugenol rate $(\mathrm{v} / \mathrm{v})$ followed by bloom stage expressed as percent of bloom open. $\mathrm{FB}=$ full bloom.

${ }^{\mathrm{y}} \mathrm{TCSA}=$ trunk cross-sectional area.

${ }^{\mathrm{x}}$ Boxes $=21.8 \mathrm{~kg}$.

"Mean separation within columns by Duncan's new multiple range test $(P \leq 0.05)$.
(Matran 2 EC or Matratec AG), and compared them with other candidate thinning agents. Results demonstrated that eugenol was an effective blossom thinner in apple and peach and that the degree of thinning was responsive to the rate of eugenol applied. Furthermore, initial injury to leaves was relatively short-lived because no sign of eugenol-induced phytotoxicity was visible 3 to 4 weeks after application and even at the highest rates ( $6 \%$ or above) where the initial injury was considered severe, signs of phytotoxicity could not be seen after 5 weeks. However, results also demonstrated a clear need for uniformity of eugenol spray coverage because variability of thinning within a canopy appeared to be associated with uneven application. Uneven flower injury was observed when eugenol was not adequately agitated in the spray tank during application and spray was applied with a hand wand or high-pressure handgun. To improve coverage and uniformity of spray deposit, an airblast sprayer was used in all tests after 2005. Although no empirical methods were used to evaluate spray coverage (i.e., water-sensitive spray cards), observation of blossoms and leaf tissue after airblast treatment clearly illustrated the improved uniformity of coverage compared with the earlier hand application. In those tests in which the sprayer fan was turned off and the spray was primarily confined to the tree canopy, uniform spray coverage was clearly visible. With a spray technology that gave improved uniform blossom coverage (airblast with or without fan operating), very clear thinning was observed with increased concentrations of eugenol, verifying the controllability and efficacy of this compound. In 2006, the thinning response to eugenol reinforced that desired thinning of peach could be obtained with an approximate concentration of $2 \%$ eugenol. In addition, an adjuvant that may improve dispersal or suspension of the eugenol in the water carrier was needed like lecithin, for example, that is used in Matran formulations.

One of the goals in fruit thinning is to obtain good return bloom for the next year (Byers, 2003). Obtaining adequate return bloom is a concern in apple in which some cultivars are inherently biennial. In peach, return bloom is seldom a concern. Return bloom was not measured in this study. However, it was observed that when bloom thinning treatments provided good levels of thinning and crop load was significantly reduced, return bloom on apple was adequate.

The importance of $\mathrm{Pn}$ in the production of carbohydrates for fruit retention and fruit growth is well established (Corelli Grappadelli, 2003; Dennis, 2000; Ferree and Palmer, 1982; Lakso et al., 1999). Young spur apple leaves play a vital role in supplying the developing fruits with carbohydrates (Corelli Grappadelli, 2003) and in fruit retention (Ferree and Palmer, 1982). A reduction in Pn after application of caustic materials at bloom (McArtney et al., 2006; Noordijk and Schupp, 2003) or from shading or Pn inhibitors (Byers et al., 1990a, 1990b) has been 
suggested as a causal factor in fruit thinning (Byers, 2003). Injury to spur leaves or shading followed by reductions in Pn could reduce fruit size. However, support for this theory from thinning trials is inconsistent (Byers et al., 1990a, 1990b; Fallahi, 1997; Fallahi et al., 1997; Noordijk and Schupp, 2003). In the present study, apple treated with Matran (Table 4) or eugenol (Tables 5 and 6) at sufficient rates to cause phytotoxicity showed no negative effects on fruit size. It should be pointed out, however, when eugenol was applied at a concentration of $3 \%$ or above (equivalent to Matran $6 \%$ or greater), there was generally a significant reduction in crop density (Tables 2-5). In some cases, the magnitude of the size increase was less than might be expected given the low crop load density. Although these findings provide no definitive proof of a negative effect of eugenol or Matran on fruit size, they suggest the potential exists. In our study, peach showed minimal foliar phytotoxicity and no negative effects on fruit size, which agrees with work by Byers (1999) with bloom thinners on peach.

Higher concentrations of eugenol quickly caused phytotoxicity and more extensive injury than lower concentrations. In addition, apple floral tissue, especially the reproductive tissue, appeared more susceptible than the same tissue in peach. In the flower, the stamen tissue appeared more susceptible to the caustic action of the eugenol than the pistil. Flowers in an early stage of bloom sustain little damage to their reproductive tissues because the petals cover the anthers and pistil. In peach, the petals often surround and protect the anthers and pistil even in late bloom. Under these conditions, spray contact can be prevented, resulting in reduced efficacy. When the floral reproductive tissue was fully exposed, severe phytotoxicity was observed with the essential oil applied to all tissue in both apple and peach, especially at rates of $4 \%$ or above.

We have investigated the use of eugenol and eugenol-containing essential oils as caustic deblossoming agents since 2003. Essential oils are considered safe and non-toxic to humans and would be suitable to organic producers. In other research, Isman et al. (2007) also reported the potential apple deblossoming use for eugenol-based clove oil but noted that the oil caused leaf and fruit russeting and was cultivar-dependent. Fruit russeting was found only in one cultivar, 'Golden Delicious', when cresylic acid and tar oil distillates were used as caustic deblossoming agents (Magness et al., 1939). The eugenol-based herbicide Matran EC was used along with eugenol to evaluate the effects of a commercial formulation on uniformity of spray and thinning. Matran EC and Matratec AG contain $50 \%$ clove oil and eugenol is the a.i. of clove oil. Eugenol alone induced a blossom-thinning dose response that translated to a reduction in fruit number as the concentration of eugenol increased. Optimal concentrations likely are between $2 \%$ and $4 \%$. The eugenol-based products may have particular value as blossom thinners in organic management systems.

Non-eugenol thinners that have similar caustic effects on blossoms were also included in these studies. Wilthin and ATS provided acceptable and comparable thinning to eugenol in peach in 2005, but ATS overthinned peach in 2006. ATS was not effective at thinning apple in 2005 but was in 2006. Like in previous experiments, thinning results with ATS and Wilthin were inconsistent. Benzylaminopurine (benzyladenine) has been used to thin apple fruitlets by stimulating ethylene biosynthesis (Angeli et al., 2004). Eugenol may stimulate ethylene synthesis as an injury response to defoliation. Clearly, defoliation can induce flower or fruit drop in apple and eugenol-induced injury to leaves likely contributed to thinning. In contrast, thinning of peach flowers by eugenol was not likely associated with foliar injury because defoliation did not affect flower or fruit drop. McAfee and Rom (2005) applied 2\% essential oils (cinnamon and cedarwood oils) to vegetative apple trees under controlled environmental conditions and reported no significant effect on Pn. They noted that clove oil was very phytotoxic and defoliated all the trees in their study. They further reported that cinnamon and cedarwood oils decreased evapotranspiration and stomatal conduction. Because clove oil defoliated trees, they were unable to measure these parameters for treated trees. More work is needed to determine the direct and indirect causes of thinning by eugenol and other essential oils in deciduous fruit crops.

Low concentrations of eugenol sprays may provide partial thinning that could be followed up with hand thinning. Partial removal of flowers at full bloom with follow-up hand thinning of small peaches at 42 DAFB increased fruit size at harvest compared with thinning at 42 DAFB alone (Myers et al., 2002). This strategy has been used to reduce costs and reliance on manual labor. Additional studies are needed to improve efficacy of the essential oils as bloom thinners, especially in peach. Multiple applications, the first at an early bloom stage and at the lower concentration, should be evaluated for increased efficacy.

\section{Conclusions}

The a.i. of several essential oils, eugenol, was determined to be effective in thinning flowers of both peach and apple when applied at concentrations between $1 \%$ and $10 \%$. Thinning increased average fruit weight and the proportion of harvested fruit in the larger size classes. Caustic injury to leaves and shoots with the eugenol was transitory with full recovery in 3 to 4 weeks in most cases and in 4 to 5 weeks at the highest rates and most severe level of observed phytotoxicity. Eugenol and the commercially available eugenol-based herbicide, Matran, were found to provide excellent peach and apple flower burn-back at concentrations between $4 \%$ and $8 \%$, but lack of uniform spray coverage increased response variation. Variability in thinning response was significantly reduced by using an airblast sprayer that enabled uniform coverage of blossoms with eugenol. The thinning effect of the essential oil on apple may be partially the result of leaf phytotoxicity and reduced photosynthetic rates as well as a direct effect on the flower reproductive tissues. Our results indicate that essential oils have potential as blossom thinners in apple and peach.

\section{Literature Cited}

Angeli, D., M. Comai, M. Danesin, A. Dorigoni, B. Ruperti, and A. Ramina. 2004. Interaction between cytokinins and ethylene in controlling thinning in apples. Rivista di Frutticoltura e di Ortofloricoltura 66:56-59.

Baugher, T.A., K.C. Elliott, B.D. Horton, S.S. Miller, and D.W. Leach. 1991. Improved methods of mechanically thinning peaches at full bloom. J. Amer. Soc. Hort. Sci. 116:766-769.

Byers, R.E. 1999. Effects of bloom-thinning chemicals on peach fruit set. J. Tree Fruit Prod. 2:5978.

Byers, R.E. 2003. Flower and fruit thinning and vegetative:fruiting balance, p. 409-436. In: Ferree, D.C. and I.J. Warrington (eds.). Apples: Botany, production and uses. CABI Publishing, Oxon, UK.

Byers, R.E., J.A. Barden, and D.H. Carbaugh. 1990a. Thinning of spur 'Delicious' apples by shade, terbacil, carbaryl, and ethephon. J. Amer. Soc. Hort. Sci. 115:9-13.

Byers, R.E., J.A. Barden, R.F. Polomski, R.W. Young, and D.H. Carbaugh. 1990b. Apple thinning by phytosynthetic inhibition. J. Amer. Soc. Hort. Sci. 115:14-19.

Byers, R.E. and D.H. Carbaugh. 1991. Effect of chemical thinning sprays on apple fruit set. HortTechnology 1:41-48.

Byers, R.E., D.H. Carbaugh, C.N. Presley, and T.K. Wolf. 1991. The influence of low light levels on apple fruit abscission. J. Hort. Sci. 66:1-17.

Byers, R.E. and C.G. Lyons, Jr. 1985. Peach flower thinning and possible sites of action of desiccating chemicals. J. Amer. Soc. Hort. Sci. 110:662-667.

Corelli Grappadelli, L. 2003. Light relations, p. 195-216. In: Ferree, D.C. and I.J. Warrington (eds.). Apples: Botany, Production and Uses. CABI Publishing, Oxon, UK

Costa, G., G. Fiori, A.M. Bregoli, M. Montefiori, and A. Orlandi. 2004. Fruit thinning in peaches: Still an unresolved problem. Rivista di Furtticoltura e di Ortofloricoltura 66:48-54.

Costa, G. and G. Vizzotto. 2000. Fruit thinning of peach trees. Plant Growth Regulat. 31:113-119.

Dennis, F.G. 2000. The history of fruit thinning. Plant Growth Regulat. 31:1-16.

Fallahi, E. 1997. Application of endothalic acid, pelargonic acid, and hydrogen cyanamide for blossom thinning in apple and peach. HortTechnology 7:395-399.

Fallahi, E., M.W. Williams, and W.M. Colt. 1997. Blossom thinning of 'Law Rome Beauty' apple with hydrogen cyanamide and monocarbamide dihydrogensulfate. J. Tree Fruit Prod. 2:33-44.

Ferree, D.C. and F.R. Hall. 1975. Influence of benomyl and oil on photosynthesis of apple leaves. HortScience 10:128-129.

Ferree, D.C. and J.W. Palmer. 1982. Effect of spur defoliation and ringing during bloom on fruiting, fruit mineral level, and net photosynthesis of 'Golden Delicious' apple. J. Amer. Soc. Hort. Sci. 107:1182-1186. 
Glenn, D.M., D.L. Peterson, D. Giovannini, and M. Faust. 1994. Mechanical thinning of peaches is effective postbloom. HortScience 29:850-853.

Isman, M.B., C.M. Machial, S. Miresmailli, and L.D. Bainard. 2007. Essential oil-based pesticides: New insights from old chemistry, p. 201-209. In: Ohkawa, H., H. Miyagawa, and P.W. Lee (eds.). Pesticide chemistry. Crop protection, public health, environmental safety. Wiley, Weinheim, Germany.

Lakso, A.N., J.N. Wünsche, J.W. Palmer, and L. Corelli Grappadelli. 1999. Measurement and modeling of carbon balance of the apple tree. HortScience 34:1040-1047.

Llewelyn, F.W.M. 1968. The effect of partial defoliation at different times in the season on fruit drop and shoot growth in Lord Lambourne apple trees. J. Hort. Sci. 43:519-526.

Magness, J.R., L.P. Batjer, and C.P. Harley. 1939. Spraying apples for blossom removal. Proc. Amer. Soc. Hort. Sci. 37:141-146.
McAfee, J. and C. Rom. 2005. Effects of essential oils on $\mathrm{CO}_{2}$ assimilation, stomatal conductance, and evapotranspiration of apple. HortScience 40:1070 (abstr.).

McArtney, S., J. Palmer, S. Davies, and S. Seymour. 2006. Effects of lime sulfur and fish oil on pollen tube growth, leaf photosynthesis and fruit set in apple. HortScience 41:357-360.

Moran, R.E., D.E. Deyton, C.E. Sams, and J.C. Cummins. 2000. Applying soybean oil to dormant peach trees thins flower buds. HortScience 35:615-619.

Myers, S.C., A.T. Savelle, D.S. Tustin, and R.E. Byers. 2002. Partial flower thinning increases shoot growth, fruit size, and subsequent flower formation of peach. HortScience 37:647-650.

Noordijk, H. and J. Schupp. 2003. Organic postbloom apple thinning with fish oil and lime sulfur. HortScience 38:690-691 (abstr.).

Schupp, J.R., T.A. Baugher, S.S. Miller, R.M. Harsh, and K.M. Lesser. 2008. Mechanical thinning of peach and apple trees reduces labor input and increases fruit size. HortTechnology 18:660-670.

Southwick, S.M., K.G. Weis, J.T. Yaeger, and H. Zhou. 1995. Controlling cropping in 'Loadel' cling peach using gibberellin: Effects on flower density, fruit distribution, fruit firmness, fruit thinning, and yield. J. Amer. Soc. Hort. Sci. 120:1087-1095

Stopar, M. 2008. Vegetable oil emulsions, $\mathrm{NaCl}$, $\mathrm{CH} 3 \mathrm{COOH}$ and $\mathrm{CaSx}$ as organically acceptable apple blossom thinning compounds. European Journal of Horticultural Science 73 . 55-61.

Tworkoski, T. 2002. Herbicide effects of essential oils. Weed Sci. 50:425-431.

Wertheim, S.J. 2000. Developments in the chemical thinning of apple and pear. Plant Growth Regulat. 31:85-100.

Wilkens, B.S., R.C. Ebel, W.A. Dozier, J. Pitts, and R. Boozer. 2004. Tergitol TMN-6 for thinning peach blossoms. HortScience 39: 1611-1613. 